\title{
An Optimal Returned Policy for a Reverse Logistics Inventory Model with Backorders
}

\author{
S. R. Singh and Neha Saxena \\ Department of Mathematics, D.N. College, Meerut 250001, India \\ Correspondence should be addressed to Neha Saxena, nancineha.saxena@gmail.com
}

Received 30 April 2012; Revised 12 September 2012; Accepted 25 September 2012

Academic Editor: Omer Benli

Copyright (c) 2012 S. R. Singh and N. Saxena. This is an open access article distributed under the Creative Commons Attribution License, which permits unrestricted use, distribution, and reproduction in any medium, provided the original work is properly cited.

\begin{abstract}
Environmental responsibility plays a significant role in the firm's agendas nowadays. In this paper, we address the environmental operations of reverse logistics. Here we developed an integrated supply chain model with coordinated production and remanufacturing due to time-dependent rates. To study the problem we consider the demand to be satisfied with newly manufactured (produced) and the remanufactured products, so there is no difference between manufactured and remanufactured items. The shortages are allowed and excess demand is backlogged as well. The returned items are collected from the end user to be remanufactured. Optimal expression is obtained for the acceptable returned quantity, maximum inventory level, production and remanufacturing scheduling period, and the total average cost. Illustrative examples, which explain the application of the theoretical results as well as their numerical verifications, are given. The sensitivity of these solutions to change in underling parameter values is also discussed.
\end{abstract}

\section{Introduction}

Environmental issues are gaining reasonable attention among society, worldwide. Consumer demand for clean manufacturing and recycling is increasing. Consumers expect to trade in an old product when they buy a new one. Hence, for the past few decades the reverse flow of products from consumers to upstream businesses has received much interest. Due to the governmental regulations and consumer concerns regarding these environmental issues, an increasing number of companies have focused on reduction efforts in the amount of waste stream, diversion of the discarded products, and disposition of the retired products properly whereas reverse logistics is the process of retrieving the product from the end consumer for the purposes of proper disposal. To facilitate the reverse flow of used products from consumers to manufacturers in an efficient manner, the most appropriate approach is to create a reverse supply chain network. Wherein reverse logistics can take place through the 
original forward channel, through a separate reverse channel, or through combinations of the forward and the reverse channel. Generally, companies focus on setting up a reverse supply chain either because of environmental regulations or to reduce their operating cost by remanufactured products or components. For companies that utilise a reverse supply chain deals with handling and reprocess of repairable used products withdrawn from production and consumption process. Such a reuse is, for example, recycling or repair of spare parts. It has an advantage from economic point of view, as reduction of environmental load through return of used items in the manufacturing process.

In the recent years researchers paid much attention to reverse logistics inventory models. There have been numerous studies and research on reverse logistics. In the past one approach adopted by many authors to the study of recovery systems is the use of Economic Ordering Quantity (EOQ) technique. The EOQ models are simple and they usually lead to closed-form solutions. The first reverse logistic model was investigated by Schrady [1]. He analyzed the problem in the EOQ model for repairable items which assumes that the production and repairing rates are instantaneous without disposal cost. Nahmias and Rivera [2] considered the model of Schrady [1] for the case of finite repair rate and limited storage in the repair and production shops. A very good review on quantitative models for recovery production planning and inventory control is given by Fleischmann et al. [3]. In this review they subdivided the field into three main areas, namely, distribution planning, inventory control, and production planning for each of these they discuss the implication of the emerging reuse efforts. There is a multiproduct generalization of EOQ-type reverse logistics models published by Mabini et al. [4]. They have extended the basic model of Schrady [1] with capital budget restriction. Richter $[5,6]$ investigated a modified version of the model of Schrady [1] by assuming multiple production and multiple repair cycles within a time interval. Most of the models investigated earlier are governed by two extreme (bang-bang) strategies, that is, "dispose all" or "recover all" [7]. In a similar work to Richter [5-7], Teunter [8] developed a deterministic EOQ inventory model with disposal option where recoverable and manufactured items have different holding costs and obtained a general finding similar to Richter [7]. Koh et al. [9] generalized the model of Nahmias and Rivera [2] by assuming a limited repair capacity. In a later study, several researchers have developed models along the same lines as Schrady and Richter, but with different assumptions, for example, Teunter [10], Inderfurth et al. [11], Dobos, and Richter [12, 13]. Dobos and Richter [14] explored their previous model by assuming that the quality of collected used items is not always suitable for further recycling. Konstantaras and Papachristos [15] have investigated an inventory model for stability. In his next work [16] he extended the work of Koh et al. [9] and followed a different analysis to obtain closed form expressions for both optimal number of set up in the recovery and the ordering processes. Konstantaras and Papachristos [17] extended the work of Teunter [10] by introducing the exact solution method for the same model. Jaber and El Saadany [18] extend the work of Richter $[5,6]$ by assuming the newly produced and remanufactured items are perceived differently by customers. Omar and Yeo [19] developed a production model that satisfies a continuous time varying demand for finished goods over a known and finite planning horizon by supplying either new products or repaired used products. The extended version of Dobos and Richter $[12,13]$ is made by El Saadany and Jaber [20] by assuming the returned rate of used items follows a demand like function depend on the purchasing price and acceptance quality level of returns. Alamri [21] derives a general reverse logistics inventory model for deteriorating items taking the returned rate as a decision variable. Another extension of Koh et al. [9] is made by Konstantaras et al. [22] by introducing the inspection and sorting of returned items. Hasanov et al. [23] extended the 


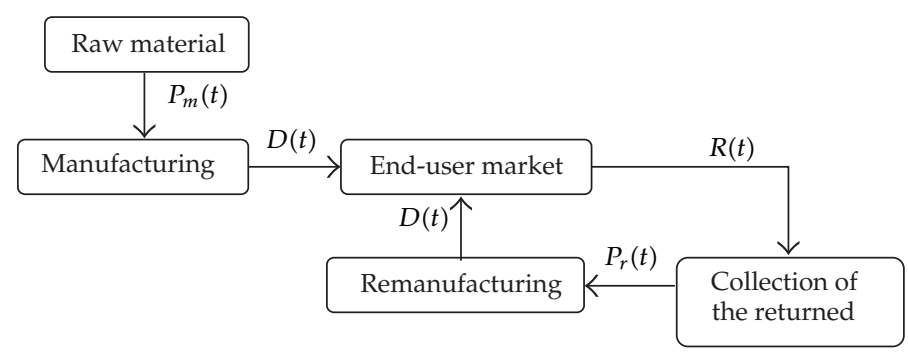

Figure 1: The flow of material in the integrated inventory model.

work Jaber and El Saadany [18] by assuming that unfulfilled demand for remanufacturing and produced items is either fully or partially backordered. This paper also considered the scenario of overlapping of one production and one remanufacturing cycle to minimize the effect of stock outs. A closed-loop supply chain inventory model is developed by Yang et al. [24], (in press). In this paper he considers price-sensitive demand and multiretailer and analysis of the problem with three optimization methods sequential optimization, a centralized optimization without benefit sharing, and a centralized optimization with benefit sharing. The comparative review is given in Table 1 .

Usually in most of the models shortages are not permitted to occur. However, in many practical situations, stock out is unavoidable due to various uncertainties. Therefore, the occurrence of shortages in inventory is a natural phenomenon. In this paper we use this phenomenon. In the proposed model we determined the coordination of reverse manufacturing with the forward supply chain in the inventory management. The reverse logistics operations deal with the collection of returns, cleaning of the collected returns, and remanufacturing of the reusable collected items. The quality of the remanufactured items is assumed to be good as those of new products hence the demand is to be satisfied with newly manufactured (produced) and the remanufactured products. A general framework of the system is shown in Figure 1. In Section 1, a comprehensive literature review and background of the model are presented. Section 2 is for assumption and notations. Section 3 demonstrates the model development. Section 4 presents the solution procedure to solve the optimization problem. Section 4.1 shows three numerical examples to illustrate the model and sensitivity analysis is presented in Section 4.2. A particular case of the given problem is given in Section 4.3 . Concluding remarks are derived and future research topics are suggested in Section 5 .

\section{Assumptions and Notations}

In this paper the subscript " $m$ " is used to indicate the quantity corresponds to the remanufactured stock, we will use the subscript " $r$ " to indicate the quantity corresponds to the remanufactured stock and the subscript " $R$ " to indicate the quantity corresponds to the returned stock.

The model is developed with the following assumptions and notations.

(i) New products are produced at a rate of $P_{m}(t)$.

(ii) Repairable used products are collected at a rate of $R(t)$ and then remanufactured at a rate of $P_{r}(t)$. All the returned items are remanufactured. 
Table 1: The comparative review in the tabular form.

\begin{tabular}{|c|c|c|c|c|c|c|}
\hline References & $\begin{array}{l}\text { Production } \\
\text { rate }\end{array}$ & $\begin{array}{l}\text { Remanufacturing/ } \\
\text { repairing rate }\end{array}$ & $\begin{array}{l}\text { Demand } \\
\text { rate }\end{array}$ & $\begin{array}{l}\text { Returned } \\
\text { rate }\end{array}$ & $\begin{array}{l}\text { The quality } \\
\text { of the } \\
\text { remanufac- } \\
\text { tured } \\
\text { items }\end{array}$ & Shortages \\
\hline Schrady [1] & $\begin{array}{c}\text { Not } \\
\text { considering }\end{array}$ & Constant & Constant & Constant & $\begin{array}{l}\text { As-good-as } \\
\text { new }\end{array}$ & $\begin{array}{l}\text { Not } \\
\text { allowed }\end{array}$ \\
\hline $\begin{array}{l}\text { Nahmias and } \\
\text { Rivera [2] }\end{array}$ & $\begin{array}{c}\text { Not } \\
\text { considering }\end{array}$ & Constant & Constant & Constant & $\begin{array}{l}\text { As-good-as } \\
\text { new }\end{array}$ & $\begin{array}{l}\text { Not } \\
\text { allowed }\end{array}$ \\
\hline Richter [5-7] & Constant & Constant & Constant & Constant & $\begin{array}{l}\text { As-good-as } \\
\text { new }\end{array}$ & $\begin{array}{c}\text { Not } \\
\text { allowed }\end{array}$ \\
\hline $\begin{array}{l}\text { Dobos and } \\
\text { Richter [12-14] }\end{array}$ & $\begin{array}{l}\text { Demand } \\
\text { dependent }\end{array}$ & $\begin{array}{l}\text { Demand } \\
\text { Dependent }\end{array}$ & Constant & $\begin{array}{l}\text { Demand } \\
\text { dependent }\end{array}$ & $\begin{array}{l}\text { As-good-as } \\
\text { new }\end{array}$ & $\begin{array}{c}\text { Not } \\
\text { allowed }\end{array}$ \\
\hline $\begin{array}{l}\text { Konstantaras } \\
\text { and } \\
\text { Papachristos } \\
{[15]}\end{array}$ & Constant & Constant & Constant & Constant & $\begin{array}{l}\text { As-good-as } \\
\text { new }\end{array}$ & $\begin{array}{l}\text { Not } \\
\text { allowed }\end{array}$ \\
\hline $\begin{array}{l}\text { Konstantaras } \\
\text { and } \\
\text { Papachristos } \\
{[16], \text { Teunter }} \\
{[10]}\end{array}$ & Constant & Constant & Constant & $\begin{array}{l}\text { Demand } \\
\text { dependent }\end{array}$ & $\begin{array}{l}\text { As-good-as } \\
\text { new }\end{array}$ & $\begin{array}{l}\text { Not } \\
\text { allowed }\end{array}$ \\
\hline $\begin{array}{l}\text { Konstantaras } \\
\text { and } \\
\text { Papachristos } \\
\text { [17], Koh et al., } \\
\text { [9] }\end{array}$ & $\begin{array}{c}\text { Not } \\
\text { considering }\end{array}$ & Constant & Constant & Constant & $\begin{array}{l}\text { As-good-as } \\
\text { new }\end{array}$ & $\begin{array}{l}\text { Not } \\
\text { allowed }\end{array}$ \\
\hline $\begin{array}{l}\text { Konstantaras } \\
\text { and Skouri, } \\
{[25]}\end{array}$ & Constant & Constant & Constant & Constant & $\begin{array}{l}\text { As-good-as } \\
\text { new }\end{array}$ & Allowed \\
\hline $\begin{array}{l}\text { Konstantaras } \\
\text { et al. [22] }\end{array}$ & $\begin{array}{c}\text { Not } \\
\text { considering }\end{array}$ & Constant & Constant & Constant & $\begin{array}{l}\text { Different } \\
\text { from the } \\
\text { new items }\end{array}$ & $\begin{array}{l}\text { Not } \\
\text { allowed }\end{array}$ \\
\hline $\begin{array}{l}\text { Jaber and El } \\
\text { Saadany, [18] }\end{array}$ & $\begin{array}{l}\text { Demand } \\
\text { dependent }\end{array}$ & $\begin{array}{l}\text { Demand } \\
\text { Dependent }\end{array}$ & Constant & $\begin{array}{l}\text { Demand } \\
\text { dependent }\end{array}$ & $\begin{array}{l}\text { Different } \\
\text { from the } \\
\text { newly } \\
\text { produced }\end{array}$ & $\begin{array}{l}\text { Not } \\
\text { allowed }\end{array}$ \\
\hline $\begin{array}{l}\text { El Saadany and } \\
\text { Jaber [20] }\end{array}$ & $\begin{array}{l}\text { Demand } \\
\text { dependent }\end{array}$ & $\begin{array}{l}\text { Demand } \\
\text { Dependent }\end{array}$ & Constant & $\begin{array}{c}\text { Price and } \\
\text { quality } \\
\text { dependent }\end{array}$ & $\begin{array}{l}\text { As-good-as } \\
\text { new }\end{array}$ & $\begin{array}{l}\text { Not } \\
\text { allowed }\end{array}$ \\
\hline $\begin{array}{l}\text { Jaber and El } \\
\text { Saadany, [26] }\end{array}$ & $\begin{array}{l}\text { Demand } \\
\text { dependent }\end{array}$ & $\begin{array}{l}\text { Demand } \\
\text { Dependent }\end{array}$ & Constant & $\begin{array}{l}\text { Demand } \\
\text { dependent }\end{array}$ & $\begin{array}{l}\text { As-good-as } \\
\text { new }\end{array}$ & $\begin{array}{l}\text { Not } \\
\text { allowed }\end{array}$ \\
\hline Alamri, [21] & $\begin{array}{l}\text { Arbitrary } \\
\text { function of } \\
\text { time }\end{array}$ & $\begin{array}{l}\text { Arbitrary function } \\
\text { of time }\end{array}$ & $\begin{array}{c}\text { Arbitrary } \\
\text { function of } \\
\text { time }\end{array}$ & $\begin{array}{c}\text { Arbitrary } \\
\text { function of } \\
\text { time }\end{array}$ & $\begin{array}{l}\text { As-good-as } \\
\text { new }\end{array}$ & $\begin{array}{l}\text { Not } \\
\text { allowed }\end{array}$ \\
\hline $\begin{array}{l}\text { Hasanov et al. } \\
\text { [23] }\end{array}$ & Constant & Constant & Constant & Constant & $\begin{array}{l}\text { Different } \\
\text { from the } \\
\text { newly } \\
\text { produced }\end{array}$ & Allowed \\
\hline $\begin{array}{l}\text { Yang et al., (in } \\
\text { press) [24] }\end{array}$ & Constant & Constant & $\begin{array}{c}\text { Price } \\
\text { sensitive }\end{array}$ & Constant & $\begin{array}{l}\text { As-good-as } \\
\text { new }\end{array}$ & $\begin{array}{c}\text { Not } \\
\text { allowed }\end{array}$ \\
\hline
\end{tabular}


Table 1: Continued.

\begin{tabular}{lccccc}
\hline References & $\begin{array}{c}\text { Production } \\
\text { rate }\end{array}$ & $\begin{array}{c}\text { Remanufacturing/ } \\
\text { repairing rate }\end{array}$ & $\begin{array}{c}\text { Demand } \\
\text { rate }\end{array}$ & $\begin{array}{c}\text { Returned } \\
\text { rate }\end{array}$ & $\begin{array}{c}\text { The quality } \\
\text { of the } \\
\text { remanufac- } \\
\text { tured } \\
\text { items }\end{array}$ \\
\hline $\begin{array}{l}\text { The present } \\
\text { paper }\end{array}$ & $\begin{array}{c}\text { Arbitrary } \\
\text { function of } \\
\text { time }\end{array}$ & $\begin{array}{c}\text { Arbitrary function } \\
\text { of time }\end{array}$ & $\begin{array}{c}\text { Arbitrary } \\
\text { function of } \\
\text { time }\end{array}$ & $\begin{array}{c}\text { Arbitrary } \\
\text { function of } \\
\text { time }\end{array}$ & $\begin{array}{c}\text { As-good-as } \\
\text { new }\end{array}$ \\
\hline
\end{tabular}

(iii) Demand is satisfied from the newly produced and remanufactured items at a rate of $D(t)$.

(iv) $P_{m}(t), R(t), P_{r}(t)$, and $D(t)$ are assumed to be arbitrary functions of time.

(v) We will require that

(a) $P_{r}(t)>D(t), P_{m}(t)>D(t), D(t)>R(t)$,

(b) $P_{r}(t)>R(t), D(t) \neq 0, R(t) \neq 0$.

(vi) Shortage is allowed and $c_{S}$ is the unit shortage cost.

(vii) Cost parameters related to manufactured products are as follows.

$I_{m}(t)$ is the inventory level at time $t$ related to manufactured products.

$q_{2}$ is the maximum inventory level in the production process.

$c_{m}$ is the unit procurement cost.

$s_{m}$ is the unit production cost.

$h_{m}$ is the unit holding cost per unit time.

$k_{m}$ is the setup cost per production cycle.

(viii) The cost parameters related to remanufactured products are as follows.

$I_{r}(t)$ is the inventory level at time $t$ related to remanufactured products.

$q_{1}$ is the maximum inventory level in the remanufacturing process.

$s_{r}$ is the unit remanufacturing cost.

$h_{r}$ is the unit holding cost per unit time.

$k_{r}$ is the setup cost per remanufacturing cycle.

(ix) The cost parameters related to returns are as follows.

$I_{R}(t)$ is the inventory level at time $t$ related to returns.

$c_{R}$ is the unit acquisition cost.

$h_{R}$ is the unit holding cost per unit time.

$k_{R}$ is the setup cost per returned cycle. 


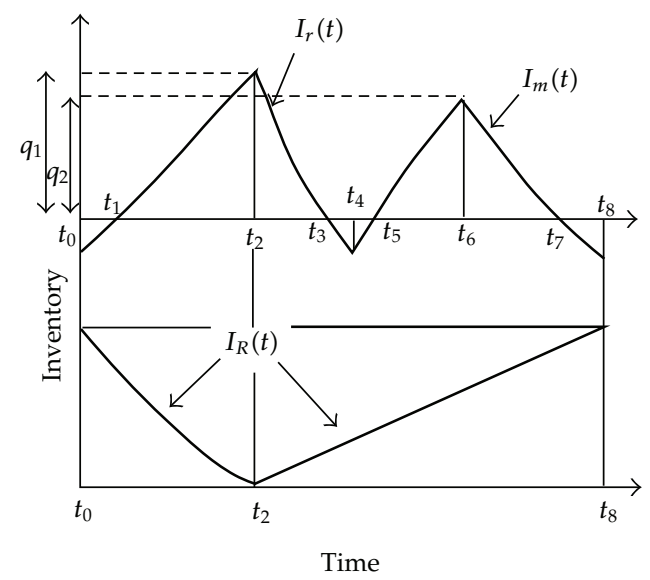

Figure 2: Inventory variation of an EPQ model for Reverse logistics system.

\section{Mathematical Modelling and Analysis}

The cycle now starts at time $t_{0}$ with backorders. At this instant of time, remanufacturing starts to clear the backlog by the time $t_{1}$ and the inventory level $I_{r}(t)$ increases at a rate $P_{r}(t)-D(t)$ until the time $t_{2}$ where stock level reaches its maximum value. Then the remanufacturing is stopped and hence the demand depletes the inventory level $I_{r}(t)$ during the period $\left(t_{2}, t_{3}\right)$ and falls to zero at $t=t_{3}$, thereafter shortages occur during the period $\left(t_{3}, t_{4}\right)$ due to the absence of stock. At this instant of time, fresh production starts to clear the backlog by the time $t_{5}$. Production raises the inventory level $I_{m}(t)$ at a rate $P_{m}(t)-D(t)$ and reaches its maximum at time $t=t_{6}$. Then the production is stopped and hence the demand depletes the inventory level $I_{m}(t)$ until the time $t_{7}$ by which it becomes zero. Now shortages start developing and accumulate to their maximum (equal to the shortage level at time $t=t_{0}$ ) at the time $t=t_{8}$. However for each returned cycle the inventory level $I_{R}(t)$ is affected by the returned rate and the remanufacturing rate, as the remanufacturing process starts at $t_{0}$, the stock level declines at a rate $R(t)-P_{r}(t)$ and falls to zero at $t=t_{2}$ by which the remanufacturing stops. Now the stock level increases at a rate $R(t)$ by the time $t=t_{8}$. This is depicted in the Figure 2 .

The differential equations governing the stock level during the period $t_{0} \leq t \leq t_{8}$ can be written as

$$
\begin{gathered}
\frac{d I_{r}(t)}{d t}=P_{r}(t)-D(t) \quad I_{r}\left(t_{1}\right)=0, t_{0} \leq t \leq t_{2}, \\
\frac{d I_{r}(t)}{d t}=-D(t) \quad I_{r}\left(t_{3}\right)=0, t_{2} \leq t \leq t_{4} \\
\frac{d I_{m}(t)}{d t}=P_{m}(t)-D(t) \quad I_{m}\left(t_{5}\right)=0, t_{4} \leq t \leq t_{6} \\
\frac{d I_{m}(t)}{d t}=-D(t) \quad I_{m}\left(t_{7}\right)=0, t_{6} \leq t \leq t_{8} \\
\frac{d I_{R}(t)}{d t}=R(t)-P_{r}(t) \quad I_{R}\left(t_{2}\right)=0, t_{0} \leq t \leq t_{2} \\
\frac{d I_{R}(t)}{d t}=R(t) \quad I_{R}\left(t_{2}\right)=0, t_{2} \leq t \leq t_{8} .
\end{gathered}
$$


Solutions of the above differential equations using their boundary conditions are

$$
\begin{gathered}
I_{r}(t)=-\int_{t}^{t_{1}}\left(P_{r}(u)-D(u)\right) d u, \quad t_{0} \leq t \leq t_{1}, \\
I_{r}(t)=\int_{t_{1}}^{t}\left(P_{r}(u)-D(u)\right) d u, \quad t_{1} \leq t \leq t_{2}, \\
I_{r}(t)=\int_{t}^{t_{3}} D(u) d u, \quad t_{2} \leq t \leq t_{3}, \\
I_{r}(t)=-\int_{t_{3}}^{t} D(u) d u, \quad t_{3} \leq t \leq t_{4}, \\
I_{m}(t)=-\int_{t}^{t_{5}}\left(P_{m}(u)-D(u)\right) d u, \quad t_{4} \leq t \leq t_{5}, \\
I_{m}(t)=\int_{t_{5}}^{t}\left(P_{m}(u)-D(u)\right) d u, \quad t_{5} \leq t \leq t_{6}, \\
I_{m}(t)=\int_{t}^{t_{7}} D(u) d u, \quad t_{6} \leq t \leq t_{7}, \\
I_{m}(t)=-\int_{t_{7}}^{t} D(u) d u, \quad t_{7} \leq t \leq t_{8}, \\
I_{R}(t)=\int_{t}^{t_{2}}\left(P_{r}(u)-R(u)\right) d u, \quad t_{0} \leq t \leq t_{2}, \\
I_{R}(t)=\int_{t_{2}}^{t} R(u) d u, \quad t_{2} \leq t \leq t_{8} .
\end{gathered}
$$

Let $I\left(x_{1}, x_{2}\right)=\int_{x_{1}}^{x_{2}} I(u) d u$, then from (3.3)-(3.6) we have

$$
\begin{gathered}
I_{r}\left(t_{0}, t_{1}\right)=-\int_{t_{0}}^{t_{1}} u\left(P_{r}(u)-D(u)\right) d u, \\
I_{r}\left(t_{1}, t_{2}\right)=\int_{t_{1}}^{t_{2}}\left(t_{2}-u\right)\left(P_{r}(u)-D(u)\right) d u, \\
I_{r}\left(t_{2}, t_{3}\right)=\int_{t_{2}}^{t_{3}}\left(u-t_{2}\right) D(u) d u, \\
I_{r}\left(t_{3}, t_{4}\right)=\int_{t_{3}}^{t_{4}}\left(u-t_{4}\right) D(u) d u, \\
I_{m}\left(t_{4}, t_{5}\right)=\int_{t_{4}}^{t_{5}}\left(t_{4}-u\right)\left(P_{m}(u)-D(u)\right) d u, \\
I_{m}\left(t_{5}, t_{6}\right)=\int_{t_{5}}^{t_{6}}\left(t_{6}-u\right)\left(P_{m}(u)-D(u)\right) d u, \\
I_{m}\left(t_{6}, t_{7}\right)=\int_{t_{6}}^{t_{7}}\left(u-t_{6}\right) D(u) d u,
\end{gathered}
$$




$$
\begin{gathered}
I_{m}\left(t_{7}, t_{8}\right)=\int_{t_{7}}^{t_{8}}\left(u-t_{8}\right) D(u) d u, \\
I_{R}\left(t_{0}, t_{2}\right)=\int_{t_{0}}^{t_{2}} u\left(P_{r}(u)-R(u)\right) d u, \\
I_{R}\left(t_{2}, t_{8}\right)=\int_{t_{2}}^{t_{8}}\left(t_{8}-u\right) R(u) d u .
\end{gathered}
$$

Without loss of generality let us assume $t_{0}=0$ then the per cycle cost components for the given inventory model are as follows:

$$
\begin{gathered}
\text { Procurement and acquisition cost }=c_{m} \int_{t_{4}}^{t_{6}} P_{m}(u) d u+c_{R} \int_{0}^{t_{8}} R(u) d u, \\
\text { Production and remanufacturing cost }=s_{m} \int_{t_{4}}^{t_{6}} P_{m}(u) d u+s_{r} \int_{0}^{t_{2}} P_{r}(u) d u,
\end{gathered}
$$

Holding cost $=h_{r}\left[I_{r}\left(t_{1}, t_{2}\right)+I_{r}\left(t_{2}, t_{3}\right)\right]+h_{m}\left[I_{m}\left(t_{5}, t_{6}\right)+I_{m}\left(t_{6}, t_{7}\right)\right]+h_{R}\left[I_{R}\left(0, t_{2}\right)+I_{R}\left(t_{2}, t_{8}\right)\right]$,

$$
\text { Shortage cost }=c_{s}\left[-I_{r}\left(0, t_{1}\right)-I_{r}\left(t_{3}, t_{4}\right)-I_{m}\left(t_{4}, t_{5}\right)-I_{m}\left(t_{7}, t_{8}\right)\right] \text {. }
$$

Hence the total cost per unit time of the given inventory model during the cycle $\left[0, t_{8}\right]$ as a function of $t_{1}, t_{2}, t_{3}, t_{4}, t_{5}, t_{6}, t_{7}$, and $t_{8}$ say $Z\left(t_{1}, t_{2}, t_{3}, t_{4}, t_{5}, t_{6}, t_{7}, t_{8}\right)$ is given by

$$
\begin{aligned}
Z\left(t_{1}, t_{2}, \ldots, t_{8}\right)=\frac{1}{t_{8}}\{ & \left(c_{m}+s_{m}\right) \int_{t_{4}}^{t_{6}} P_{m}(u) d u+c_{R} \int_{0}^{t_{8}} R(u) d u+s_{r} \int_{0}^{t_{2}} P_{r}(u) d u \\
& +h_{r}\left[\int_{t_{1}}^{t_{2}}\left(t_{2}-u\right)\left(P_{r}(u)-D(u)\right) d u+\int_{t_{2}}^{t_{3}}\left(t-t_{2}\right) D(u) d u\right] \\
& +h_{m}\left[\int_{t_{5}}^{t_{6}}\left(t_{6}-u\right)\left(P_{m}(u)-D(u)\right) d u+\int_{t_{6}}^{t_{7}}\left(u-t_{6}\right) D(u) d u\right] \\
& +h_{R}\left[\int_{0}^{t_{2}} u\left(P_{r}(u)-R(u)\right) d u+\int_{t_{2}}^{t_{8}}\left(t_{8}-u\right) R(u) d u\right] \\
& +c_{s}\left[\int_{0}^{t_{1}} u\left(P_{r}(u)-D(u)\right) d u-\int_{t_{3}}^{t_{4}}\left(u-t_{4}\right) D(u) d u-\int_{t_{4}}^{t_{5}}\left(t_{4}-u\right)\right. \\
& \left.\left.\times\left(P_{m}(u)-D(u)\right) d u-\int_{t_{7}}^{t_{8}}\left(u-t_{8}\right) D(u) d u\right]+k_{r}+k_{m}+k_{R}\right\} .
\end{aligned}
$$


Here we have a cost function of the system in terms of $t_{1}, t_{2}, t_{3}, t_{4}, t_{5}, t_{6}, t_{7}$, and $t_{8}$. To find the optimum solution we have to find the optimum value of $t_{1}, t_{2}, t_{3}, t_{4}, t_{5}, t_{6}, t_{7}$, and $t_{8}$ that minimize $Z\left(t_{1}, t_{2}, \ldots, t_{8}\right)$ but we have some relations between the variables as follows.

$$
\begin{gathered}
0 \leq t_{1} \leq t_{2} \leq t_{3} \leq t_{4} \leq t_{5} \leq t_{6} \leq t_{7} \leq t_{8} \\
\int_{t_{1}}^{t_{2}}\left(P_{r}(t)-D(t)\right) d t=\int_{t_{2}}^{t_{3}} D(t) d t \\
\int_{t_{3}}^{t_{4}} D(t) d t=\int_{t_{4}}^{t_{5}}\left(P_{m}(t)-D(t)\right) d t \\
\int_{t_{5}}^{t_{6}}\left(P_{m}(t)-D(t)\right) d t=\int_{t_{6}}^{t_{7}} D(t) d t \\
\int_{0}^{t_{1}}\left(P_{r}(t)-D(t)\right) d t=\int_{t_{7}}^{t_{8}} D(t) d t \\
\int_{0}^{t_{8}} R(t) d t=\int_{0}^{t_{2}} P_{r}(t) d t .
\end{gathered}
$$

Equation (3.10) is an essential condition for the existence of the model. Equation (3.11) show that the inventory levels $I_{r}(t)$ are same at the time $t=t_{2}$, similarly (3.12) and (3.13) show that the inventory level $I_{m}(t)$ and $I_{r}(t)$ are same at the time $t=t_{4}$ and $t=t_{6}$, respectively, depicted in Figure 2. Equation (3.14) shows that the backorders at the time $t=0$ and $t=t_{8}$ are alike as we have already assumed in the formulation of model. According to the presented model all the units buyback from the market will be remanufactured (no disposal) hence the total remanufacturing during the cycle is equal to the total returned items in the complete cycle which is demonstrated in (3.15).

\section{Solution Procedure}

Let $Q$ be the acceptable returned quantity for used items in the interval $\left[0, t_{8}\right]$ :

$$
Q=\int_{0}^{t_{8}} R(u) d u
$$

And let we have the maximum inventory level $q_{1}$ and $q_{2}$ in remanufacturing and production process, respectively, so that from (3.11) and (3.13) we get

$$
\begin{aligned}
& \int_{t_{1}}^{t_{2}}\left(P_{r}(t)-D(t)\right) d t=\int_{t_{2}}^{t_{3}} D(t) d t=q_{1} \\
& \int_{t_{5}}^{t_{6}}\left(P_{m}(t)-D(t)\right) d t=\int_{t_{6}}^{t_{7}} D(t) d t=q_{2} .
\end{aligned}
$$

Therefore from (3.11), (3.12),.., (4.2), and (4.3) the value of $t_{1}, t_{2}, t_{3}, t_{4}, t_{5}, t_{6}, t_{7}$, and $t_{8}$ can be determined as a function of $Q, q_{1}$, and $q_{2}$. 
Therefore the total variable cost function will be the function of three variables $Q, q_{1}$, and $q_{2}$ which is $Z\left(Q, q_{1}, q_{2}\right)$ :

$$
\begin{aligned}
Z\left(Q, q_{1}, q_{2}\right)=\frac{1}{t_{8}}\{ & \left(c_{m}+s_{m}\right) \int_{t_{4}}^{t_{6}} P_{m}(u) d u+c_{R} \int_{0}^{t_{8}} R(u) d u+s_{r} \int_{0}^{t_{2}} P_{r}(u) d u \\
& +h_{r}\left[\int_{t_{1}}^{t_{2}}(-u)\left(P_{r}(u)-D(u)\right) d u+\int_{t_{2}}^{t_{3}} u D(u) d u\right] \\
& +h_{m}\left[\int_{t_{5}}^{t_{6}}(-u)\left(P_{m}(u)-D(u)\right) d u+\int_{t_{6}}^{t_{7}} u D(u) d u\right] \\
& +h_{R}\left[\int_{0}^{t_{2}} u\left(P_{r}(u)-R(u)\right) d u+\int_{t_{2}}^{t_{8}}\left(f_{8}-u\right) R(u) d u\right] \\
& +c_{s}\left[\int_{0}^{t_{1}} u\left(P_{r}(u)-D(u)\right) d u-\int_{t_{3}}^{t_{4}} u D(u) d u+\int_{t_{4}}^{t_{5}} u\left(P_{m}(u)-D(u)\right) d u\right. \\
& \left.\left.-\int_{t_{7}}^{t_{8}} u D(u) d u\right]+k_{r}+k_{m}+k_{R}\right\}
\end{aligned}
$$

where the values of $t_{1}, t_{2}, t_{3}, t_{4}, t_{5}, t_{6}, t_{7}$, and $t_{8}$ are given in the next section.

To obtain the optimal solution of the proposed problem, we minimize the functions $Z\left(Q, q_{1}, q_{2}\right)$ with respect to $Q, q_{1}$, and $q_{2}$ Taking the first order derivatives of $Z\left(Q, q_{1}, q_{2}\right)$ with respect to $Q, q_{1}$, and $q_{2}$. Thereafter setting it equal to zero gives

$$
\begin{aligned}
& \frac{\partial Z\left(Q, q_{1}, q_{2}\right)}{\partial Q}=0, \\
& \frac{\partial Z\left(Q, q_{1}, q_{2}\right)}{\partial q_{1}}=0, \\
& \frac{\partial Z\left(Q, q_{1}, q_{2}\right)}{\partial q_{2}}=0 .
\end{aligned}
$$

The optimal value of $Q, q_{1}$, and $q_{2}$ can be derived from the above equations when the following conditions of Hessian matrix are satisfied. The Hessian matrix is

$$
H=\left(\begin{array}{ccc}
\frac{\partial^{2} Z}{\partial Q^{2}} & \frac{\partial^{2} Z}{\partial Q q_{1}} & \frac{\partial^{2} Z}{\partial Q q_{2}} \\
\frac{\partial^{2} Z}{\partial q_{1} Q} & \frac{\partial^{2} Z}{\partial q_{1}^{2}} & \frac{\partial^{2} Z}{\partial q_{1} q_{2}} \\
\frac{\partial^{2} Z}{\partial q_{2} Q} & \frac{\partial^{2} Z}{\partial q_{2} q_{1}} & \frac{\partial^{2} Z}{\partial q_{2}^{2}}
\end{array}\right)
$$


The first principal minor determinant of $H,\left|H_{11}\right|>0$. The second principal minor determinant of $H,\left|H_{22}\right|>0$ and the third principal minor determinant of $H,\left|H_{33}\right|>0$.

\subsection{Illustrative Examples with Numerical Analysis}

Example 4.1. The model is developed with linearly time-dependent demand, production, remanufacturing, and returned rates, in this example we consider

$$
P_{m}(t)=a_{m}+b_{m} t, \quad P_{r}(t)=a_{r}+b_{r} t, \quad R(t)=c+d t, \quad D(t)=\alpha+\beta t .
$$

On the basis of these above demand, production, remanufacturing, and returned rates we calculate the theoretical results and the total cost function as defined in the previous section.

From (4.1) we have

$$
Q=\int_{0}^{t_{8}} R(u) d u=\int_{0}^{t_{8}}(c+d u) d u=\frac{d t_{8}^{2}}{2}+c t_{8}
$$

From which $t_{8}$ is given by

$$
t_{8}=\frac{-c+\sqrt{c^{2}+2 d Q}}{d}
$$

From (3.15) and (4.1) we have

$$
Q=\int_{0}^{t_{8}} R(u) d u=\int_{0}^{t_{2}} P_{r}(u) d u=\int_{0}^{t_{8}}\left(a_{r}+b_{r} u\right) d u .
$$

Hence $t_{2}$ is given by

$$
t_{2}=\frac{-a_{r}+\sqrt{a_{r}^{2}+2 b_{r} Q}}{b_{r}}
$$

From (4.2) we get

$$
\begin{gathered}
\int_{t_{1}}^{t_{2}}\left(P_{r}(t)-D(t)\right) d t=q_{1} \\
\left(a_{r}-\alpha\right)\left(t_{2}-t_{1}\right)+\frac{\left(b_{r}-\beta\right)}{2}\left(t_{2}^{2}-t_{1}^{2}\right)=q_{1} .
\end{gathered}
$$

By which we can find $t_{1}$, say

$$
t_{1}=\frac{-2 a_{r}+2 \alpha+\sqrt{\left(2 a_{r}-2 \alpha\right)^{2}-4\left(b_{r}-\beta\right)\left(2 q_{1}-2 a_{r} t_{2}-b_{r} t_{2}^{2}+2 t_{2} \alpha+t_{2}^{2} \beta\right)}}{2\left(b_{r}-\beta\right)} .
$$


From (4.2) we have

$$
\begin{gathered}
\int_{t_{2}}^{t_{3}} D(t) d t=q_{1} \\
\alpha\left(t_{3}-t_{2}\right)+\frac{\beta}{2}\left(t_{3}^{2}-t_{2}^{2}\right)=q_{1} .
\end{gathered}
$$

From which we can find $t_{3}$, say

$$
t_{3}=\frac{-\alpha+\sqrt{\alpha^{2}+2 q_{1} \beta+2 t_{2} \alpha \beta+t_{2}^{2} \beta^{2}}}{\beta} .
$$

From (3.14) we have

$$
\begin{gathered}
\int_{0}^{t_{1}}\left(P_{r}(t)-D(t)\right) d t=\int_{t_{7}}^{t_{8}} D(t) d t \\
\left(a_{r}-\alpha\right) t_{1}+\frac{\left(b_{r}-\beta\right)}{2} t_{1}^{2}=\alpha\left(t_{8}-t_{7}\right)+\frac{\beta}{2}\left(t_{8}^{2}-t_{7}^{2}\right) .
\end{gathered}
$$

Hence the value of $t_{7}$ is given by

$$
t_{7}=\frac{-\alpha+\sqrt{\alpha^{2}-2 a_{r} t_{1} \beta-b_{r} t_{1}^{2} \beta+2 t_{1} \alpha \beta+2 t_{8} \alpha \beta+t_{1}^{2} \beta^{2}+t_{8}^{2} \beta^{2}}}{\beta} .
$$

From (4.3) we have

$$
\begin{aligned}
& \int_{t_{6}}^{t_{7}} D(t) d t=q_{2} \\
& \Longrightarrow \alpha\left(t_{7}-t_{6}\right)+\frac{\beta}{2}\left(t_{7}^{2}-t_{6}^{2}\right)=q_{2} .
\end{aligned}
$$

From which we can determine the value of $t_{6}$, say

$$
t_{6}=\frac{-\alpha+\sqrt{\alpha^{2}-2 q_{2} \beta+2 t_{7} \alpha \beta+t_{7}^{2} \beta^{2}}}{\beta} .
$$

Similarly from (4.3)

$$
\int_{t_{5}}^{t_{6}}\left(P_{m}(t)-D(t)\right) d t=q_{2} .
$$


Table 2: The optimal results for the inventory model under the above parametric values as in Example 4.2.

\begin{tabular}{lccccccccccc}
\hline$Q^{*}$ & $q_{1}^{*}$ & $q_{2}^{*}$ & $t_{1}^{*}$ & $t_{2}^{*}$ & $t_{3}^{*}$ & $t_{4}^{*}$ & $t_{5}^{*}$ & $t_{6}^{*}$ & $t_{7}^{*}$ & $t_{8}^{*}$ & $Z\left(Q^{*}, q_{1}^{*}, q_{2}^{*}\right)$ \\
\hline 1712 & 781 & 191 & 0.160528 & 0.94369 & 1.86346 & 1.92922 & 2.01177 & 2.28889 & 2.50498 & 2.6851 & 7616.1 \\
units units & units & Month & month & month & Month & month & Month & Month & month & $\$$ \\
\hline
\end{tabular}

From which we can find $t_{5}$

$$
t_{5}=\frac{-2 a_{m}+2 \alpha+\sqrt{\left(2 a_{m}-2 \alpha\right)^{2}-4\left(b_{m}-\beta\right)\left(2 q_{2}-2 a_{m} t_{6}-b_{m} t_{6}^{2}+2 t_{6} \alpha+t_{6}^{2} \beta\right)}}{2\left(b_{m}-\beta\right)} .
$$

From (3.12) we have

$$
\begin{gathered}
\int_{t_{3}}^{t_{4}} D(t) d t=\int_{t_{4}}^{t_{5}}\left(P_{m}(t)-D(t)\right) d t \\
\left(a_{m}-\alpha\right)\left(t_{5}-t_{4}\right)+\frac{\left(b_{m}-\beta\right)}{2}\left(t_{5}^{2}-t_{4}^{2}\right)=\alpha\left(t_{4}-t_{3}\right)+\frac{\beta}{2}\left(t_{4}^{2}-t_{3}^{2}\right) .
\end{gathered}
$$

From which we can find $t_{4}$

$$
t_{4}=\frac{-a_{m}+\sqrt{a_{m}^{2}+2 a_{m} b_{m} t_{5}+b_{m}^{2} t_{5}^{2}+2 b_{m} t_{3} \alpha-2 b_{m} t_{5} \alpha+b_{m} t_{3}^{2} \beta-b_{m} t_{5}^{2} \beta}}{b_{m}} .
$$

Example 4.2. The above theoretical results are illustrated through the numerical verification. To illustrate the proposed model, we have considered the input parameters as given below.

$c_{m}=8 \$ /$ unit, $s_{m}=3 \$ /$ unit, $s_{r}=2 \$ /$ unit, $c_{R}=2 \$ /$ unit, $c_{s}=5 \$ /$ unit, $a_{m}=$ 1500 unit $/ \mathrm{month}, b_{m}=30$ unit $/ \mathrm{month}^{2}, \alpha=800 \mathrm{unit} / \mathrm{month}, \beta=35 \mathrm{unit} / \mathrm{month}^{2}, a_{r}=$ 1800 unit $/$ month, $b_{r}=30$ unit $/ \mathrm{month}^{2}, h_{R}=1 \$ /$ unit $/$ month, $h_{m}=1.5 \$ /$ unit $/ \mathrm{month}, k_{m}=$ $1500 \$ /$ cycle, $k_{R}=1000 \$ /$ cycle, $h_{r}=1 \$ /$ unit $/$ month, $k_{r}=800 \$ /$ cycle, $c=600$ unit $/ \mathrm{month}$, $d=28 \mathrm{unit} / \mathrm{month}^{2}$.

Applying the solution procedure given in the last section we derive the optimal solution and results are presented in Table 2 .

The convexity of the reverse logistics inventory model is shown in Figure 3 . The three dimensional graph shows that the integrated expected total annual cost is convex, and that there exists a unique solution minimizing the integrated expected total annual cost.

\subsection{Sensitivity Analysis}

To study the effects of the parameter changes on the optimal solutions derived by the proposed method, this investigation performs a sensitivity analysis by increasing or decreasing the parameters, one at a time.

The main conclusions drawn from the sensitivity analysis given above are as follows.

(i) From Tables 3 and 4 we have observed that as the production rate increases the optimum value of total acceptable returned quantity decreases and hence the total 


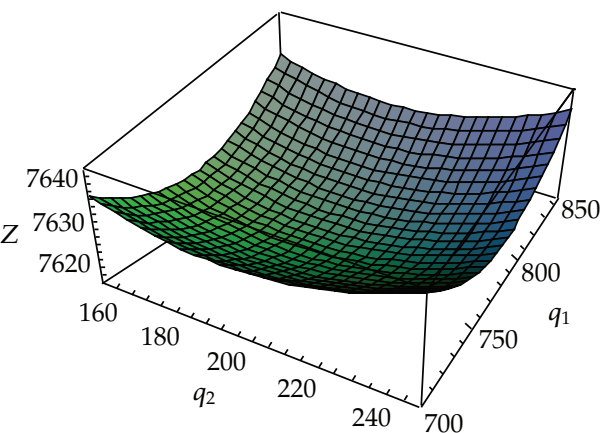

(a)

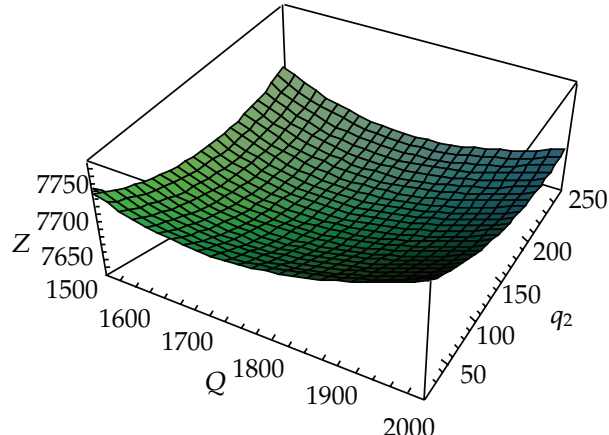

(b)

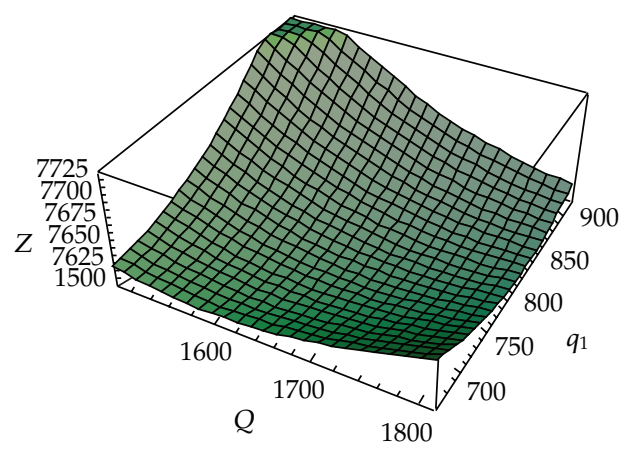

(c)

Figure 3: Convexity of the reverse logistics inventory model is derived, and when the optimal value of acceptable returned quantity $Q$, maximum inventory level $q_{1}$ and $q_{2}$ is taken.

minimum cost slightly decreases. However we observe a little but unexpected increment in the total minimum average cost and this increment happened due to the reduction in total cycle length.

(ii) Similarly from Tables 5 and 6 we have observed that as the remanufacturing rate increases the optimum value of total acceptable returned quantity decreases and hence the total minimum cost slightly decreases. But due to the reduction in total cycle length we observe a little increment in the total minimum average cost.

(iii) From Tables 7 and 8 it is observed that as the return rate increases the optimum value of total acceptable returned quantity increases while the total time required to produce the optimum manufactured quantity decrease. Hence the total procurement and production cost will decrease. This reduction resulted in the decrease in the total minimum average cost.

(iv) Similarly from Table 9 it is observed that as the constant demand rate increases the optimal values of total acceptable returned quantity and the total time required to produce the optimum manufactured quantity increase. Hence the total procurement, acquisition, and production cost increases. This increment resulted in the increase in the total minimum average cost per cycle.

(v) Now from Table 10 it is observed that as the variable demand rate increases the optimal values of total acceptable returned quantity decrease and hence the total 
Table 3: For the different constant production rates optimal results for the same set of values as in Example 4.2.

\begin{tabular}{lcccccccccccc}
\hline$a_{m}$ & $Q^{*}$ & $q_{1}^{*}$ & $q_{2}^{*}$ & $t_{1}^{*}$ & $t_{2}^{*}$ & $t_{3}^{*}$ & $t_{4}^{*}$ & $t_{5}^{*}$ & $t_{6}^{*}$ & $t_{7}^{*}$ & $t_{8}^{*}$ & $Z\left(Q^{*}, q_{1}^{*}, q_{2}^{*}\right)$ \\
\hline 1200 & 1719 & 785 & 134 & 0.1603 & 0.9475 & 1.8717 & 1.9177 & 2.0198 & 2.3642 & 2.5156 & 2.6954 & 7605.77 \\
1350 & 1715 & 783 & 165 & 0.1601 & 0.9453 & 1.8673 & 1.9249 & 2.0173 & 2.3233 & 2.5098 & 2.6895 & 7611.48 \\
1500 & 1712 & 781 & 191 & 0.1605 & 0.9436 & 1.8634 & 1.9292 & 2.0117 & 2.2888 & 2.5049 & 2.6851 & 7616.1 \\
1650 & 1709 & 780 & 212 & 0.1598 & 0.9420 & 1.8607 & 1.9335 & 2.0086 & 2.2612 & 2.5012 & 2.6806 & 7619.9 \\
1800 & 1707 & 779 & 229 & 0.1598 & 0.9409 & 1.8585 & 1.9379 & 2.0075 & 2.2389 & 2.49833 & 2.6777 & 7623.08 \\
\hline
\end{tabular}

Table 4: Optimal results for the same set of values as in Example 4.2 for different variable production rates.

\begin{tabular}{|c|c|c|c|c|c|c|c|c|c|c|c|}
\hline$b_{m} Q^{*}$ & $q_{1}^{*}$ & $q_{2}^{*}$ & $t_{1}^{*}$ & $t_{2}^{*}$ & $t_{3}^{*}$ & $t_{4}^{*}$ & $t_{5}^{*}$ & $t_{6}^{*}$ & $t_{7}^{*}$ & $t_{8}^{*}$ & $Z\left(Q^{*}, q_{1}^{*}, q_{2}^{*}\right)$ \\
\hline 281712 & 782 & 190 & 0.159527 & 0.94369 & 1.86462 & 1.93053 & 2.01376 & 2.29116 & 2.5061 & 2.6851 & 7615.98 \\
\hline 291712 & 781 & 191 & 0.160528 & 0.94369 & 1.86346 & 1.92873 & 2.01091 & 2.28889 & 2.50498 & 2.6851 & 7616.04 \\
\hline 301712 & 781 & 191 & 0.160528 & 0.94369 & 1.86346 & 1.92922 & 2.01177 & 2.28889 & 2.50498 & 2.6851 & 7616.1 \\
\hline 311711 & 781 & 191 & 0.159983 & 0.943143 & 1.86293 & 1.92902 & 2.01175 & 2.288 & 2.5041 & 2.68362 & 7616.15 \\
\hline 321711 & 781 & 191 & 0.159983 & 0.943143 & 1.86293 & 1.92951 & 2.01261 & 2.288 & 2.5041 & 2.68362 & 7616.21 \\
\hline
\end{tabular}

minimum cost slightly decreases. But due to the reduction in total cycle length we observe a little increment in the total minimum average cost.

\subsection{A Particular Case When $q_{1}$ and $q_{2}$ Are Constant}

In a particular case let us have $q_{1}$ and $q_{2}$ the maximum inventory level in the remanufacturing and production process, as a constant then from (4.9)-(4.23) the values of $t_{1}, t_{2}, t_{3}, t_{4}, t_{5}, t_{6}, t_{7}$, and $t_{8}$ can be found in the form of single variable $Q$, say

$$
t_{i}=f_{i}(Q), \quad \text { where } 1 \leq i \leq 8
$$

From (4.4) the total cost function will be the function of one variable, say $Q$ and the problem will be converted into the following unconstrained problem with one variable $Q$ :

$$
\begin{aligned}
W(Q)=\frac{1}{f_{8}}\left\{\left(c_{m}+s_{m}\right) \int_{f_{4}}^{f_{6}} P_{m}(u) d u+c_{R} \int_{0}^{f_{8}} R(u) d u+s_{r} \int_{0}^{f_{2}} P_{r}(u) d u\right. \\
+h_{r}\left[\int_{f_{1}}^{f_{2}}(-u)\left(P_{r}(u)-D(u)\right) d u+\int_{f_{2}}^{f_{3}} u D(u) d u\right] \\
+h_{m}\left[\int_{f_{5}}^{f_{6}}(-u)\left(P_{m}(u)-D(u)\right) d u+\int_{f_{6}}^{f_{7}} u D(u) d u\right] \\
+h_{R}\left[\int_{0}^{f_{2}} u\left(P_{r}(u)-R(u)\right) d u+\int_{f_{2}}^{f_{8}}\left(f_{8}-u\right) R(u) d u\right]
\end{aligned}
$$


Table 5: Optimal results for the same set of values as in Example 4.2 for different constant remanufacturing rates.

\begin{tabular}{|c|c|c|c|c|c|c|c|c|c|c|c|c|}
\hline$a_{r}$ & $Q^{*}$ & $q_{1}^{*}$ & $q_{2}^{*}$ & $t_{1}^{*}$ & $t_{2}^{*}$ & $t_{3}^{*}$ & $t_{4}^{*}$ & $t_{5}^{*}$ & $t_{6}^{*}$ & $t_{7}^{*}$ & $t_{8}^{*}$ & $Z\left(Q^{*}, q_{1}^{*}, q_{2}^{*}\right)$ \\
\hline 1440 & 1823 & 661 & 202 & 0.2109 & 1.2497 & 2.0207 & 2.0903 & 2.1782 & 2.4717 & 2.69856 & 2.8489 & 7479.26 \\
\hline 1620 & 1759 & 730 & 202 & 0.1814 & 1.0751 & 1.9312 & 1.9914 & 2.0671 & 2.3603 & 2.5882 & 2.7546 & 7556.35 \\
\hline 1800 & 1712 & 781 & 191 & 0.1605 & 0.9436 & 1.8634 & 1.9292 & 2.0117 & 2.2888 & 2.5049 & 2.6851 & 7616.1 \\
\hline 1980 & 1676 & 822 & 187 & 0.1430 & 0.8411 & 1.8122 & 1.8772 & 1.9586 & 2.2298 & 2.44188 & 2.6317 & 7663.79 \\
\hline 2160 & 1648 & 855 & 184 & 0.1292 & 0.7589 & 1.7716 & 1.8359 & 1.9161 & 2.1829 & 2.39203 & 2.5901 & 7702.75 \\
\hline
\end{tabular}

Table 6: Optimal results for the same set of values as in Example 4.2 for different variable remanufacturing rates.

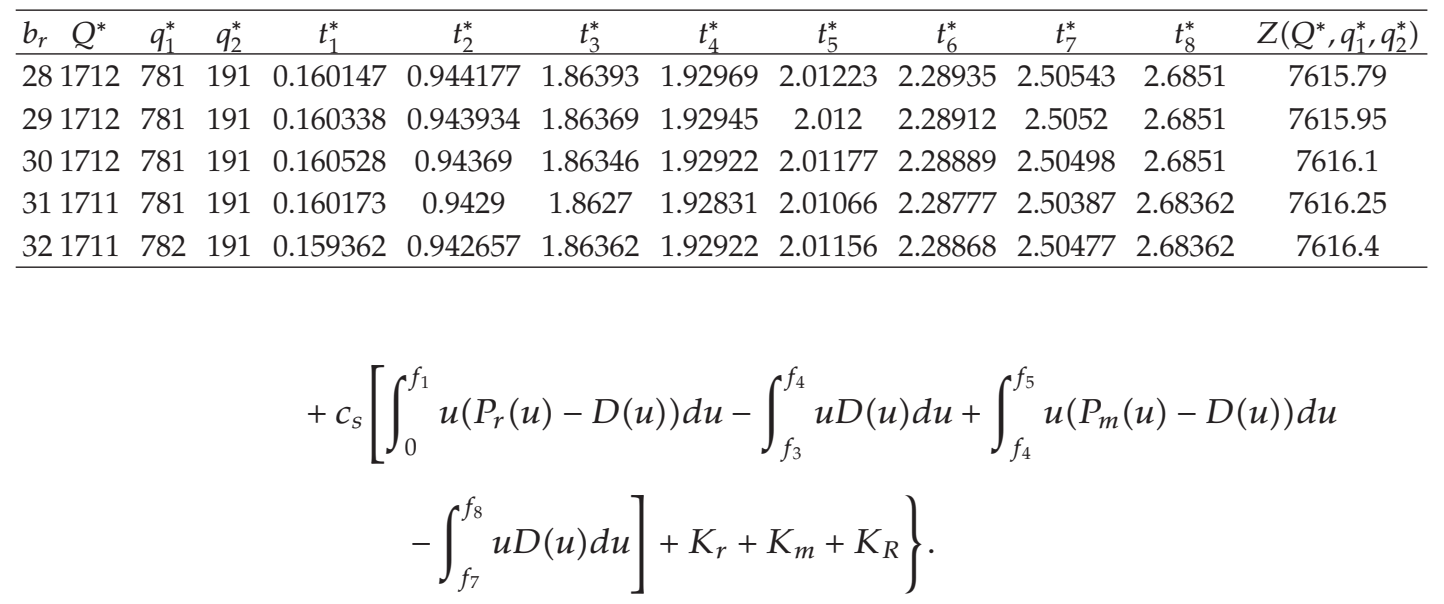

Now the necessary conditions for having a minimum for the problem

$$
\frac{d W}{d Q}=0
$$

To find the solution of (4.26), let $W=w / f_{8}$ then

$$
\frac{d W}{d Q}=\frac{w_{Q}^{\prime} f_{8}-f_{8 . Q}^{\prime} w}{f_{8}^{2}}
$$

where, $w_{Q}^{\prime}$ and $f_{8 . Q}^{\prime}$ are the derivatives of $w$ and $f_{8}$ (w.r.t.) $Q$, respectively. Hence, (4.26) is equivalent to

$$
w_{Q}^{\prime} f_{8}=f_{8 \cdot Q}^{\prime} w
$$


Table 7: Optimal results for the same set of values as in Example 4.2 for different constant return rates.

\begin{tabular}{lcccccccccccc}
\hline$c$ & $Q^{*}$ & $q_{1}^{*}$ & $q_{2}^{*}$ & $t_{1}^{*}$ & $t_{2}^{*}$ & $t_{3}^{*}$ & $t_{4}^{*}$ & $t_{5}^{*}$ & $t_{6}^{*}$ & $t_{7}^{*}$ & $t_{8}^{*}$ & $Z\left(Q^{*}, q_{1}^{*}, q_{2}^{*}\right)$ \\
\hline 480 & 1460 & 668 & 315 & 0.1490 & 0.8769 & 1.7353 & 1.9548 & 2.2299 & 2.5963 & 2.87761 & 3.0425 & 8251.8 \\
540 & 1590 & 726 & 252 & 0.1490 & 0.8769 & 1.7353 & 1.8226 & 1.9316 & 2.2971 & 2.58178 & 2.7485 & 7917.36 \\
600 & 1712 & 781 & 191 & 0.1605 & 0.9436 & 1.8634 & 1.9292 & 2.0117 & 2.2888 & 2.5049 & 2.6851 & 7616.1 \\
660 & 1826 & 833 & 133 & 0.1705 & 1.0060 & 1.9833 & 2.0284 & 2.0853 & 2.2783 & 2.42905 & 2.6209 & 7318.71 \\
720 & 1934 & 882 & 77 & 0.1802 & 1.0649 & 2.0961 & 2.1226 & 2.1562 & 2.2680 & 2.35546 & 2.5588 & 7024.89 \\
\hline
\end{tabular}

Table 8: Optimal results for the same set of values as in Example 4.2 for different variable return rates.

\begin{tabular}{lccccccccccc}
\hline$d \quad Q^{*}$ & $q_{1}^{*}$ & $q_{2}^{*}$ & $t_{1}^{*}$ & $t_{2}^{*}$ & $t_{3}^{*}$ & $t_{4}^{*}$ & $t_{5}^{*}$ & $t_{6}^{*}$ & $t_{7}^{*}$ & $t_{8}^{*}$ & $Z\left(Q^{*}, q_{1}^{*}, q_{2}^{*}\right)$ \\
\hline 261697 & 775 & 192 & 0.15836 & 0.935485 & 1.84862 & 1.9157 & 1.99985 & 2.2784 & 2.4957 & 2.67347 & 7629.03 \\
271704 & 778 & 192 & 0.159172 & 0.939314 & 1.85578 & 1.92156 & 2.0041 & 2.28265 & 2.49992 & 2.67857 & 7622.57 \\
281712 & 781 & 191 & 0.160528 & 0.94369 & 1.86346 & 1.92922 & 2.01177 & 2.28889 & 2.50498 & 2.6851 & 7616.1 \\
291719 & 785 & 190 & 0.160338 & 0.947518 & 1.87177 & 1.93732 & 2.01965 & 2.29532 & 2.51023 & 2.69011 & 7609.62 \\
301711 & 782 & 191 & 0.161149 & 0.951347 & 1.87892 & 1.94426 & 2.02635 & 2.30059 & 2.51432 & 2.69508 & 7603.14 \\
\hline
\end{tabular}

Taking the first derivative of both sides of (3.11), (3.12), (3.13), (3.14), and (3.15) with respect to $Q$. We obtain

$$
\begin{gathered}
f_{2 . Q}^{\prime}\left(P_{r}\left(f_{2}\right)-D\left(f_{2}\right)\right)-f_{1 . Q}^{\prime}\left(P_{r}\left(f_{1}\right)-D\left(f_{1}\right)\right)=f_{3 . Q}^{\prime} D\left(f_{3}\right)-f_{2 . Q}^{\prime} D\left(f_{2}\right), \\
f_{4 . Q}^{\prime} D\left(f_{4}\right)-f_{3 . Q}^{\prime} D\left(f_{3}\right)=f_{5 . Q}^{\prime}\left(P_{m}\left(f_{5}\right)-D\left(f_{5}\right)\right)-f_{4 . Q}^{\prime}\left(P_{m}\left(f_{4}\right)-D\left(f_{4}\right)\right), \\
f_{6 . Q}^{\prime}\left(P_{m}\left(f_{6}\right)-D\left(f_{6}\right)\right)-f_{5 . Q}^{\prime}\left(P_{m}\left(f_{5}\right)-D\left(f_{5}\right)\right)=f_{7 . Q}^{\prime} D\left(f_{7}\right)-f_{6 . Q}^{\prime} D\left(f_{6}\right), \\
f_{1 . Q}^{\prime}\left(P_{r}\left(f_{1}\right)-D\left(f_{1}\right)\right)=f_{8 . Q}^{\prime} D\left(f_{8}\right)-f_{7 . Q}^{\prime} D\left(f_{7}\right), \\
f_{8 . Q}^{\prime} R\left(f_{8}\right)=f_{2 . Q}^{\prime} P_{r}\left(f_{2}\right) .
\end{gathered}
$$

As we have $q_{1}$ and $q_{2}$ are constant so that from (4.2) and (4.3) both sides of (4.29) and (4.30) will be equal to zero

$$
\begin{aligned}
& f_{2 \cdot Q}^{\prime}\left(P_{r}\left(f_{2}\right)-D\left(f_{2}\right)\right)-f_{1 . Q}^{\prime}\left(P_{r}\left(f_{1}\right)-D\left(f_{1}\right)\right)=f_{3 \cdot Q}^{\prime} D\left(f_{3}\right)-f_{2 \cdot Q}^{\prime} D\left(f_{2}\right)=0 \\
& f_{4 . Q}^{\prime} D\left(f_{4}\right)-f_{3 . Q}^{\prime} D\left(f_{3}\right)=f_{5 . Q}^{\prime}\left(P_{m}\left(f_{5}\right)-D\left(f_{5}\right)\right)-f_{4 . Q}^{\prime}\left(P_{m}\left(f_{4}\right)-D\left(f_{4}\right)\right)=0 .
\end{aligned}
$$

Form the above equation we can find the values of $f_{1 . Q^{\prime}}^{\prime} f_{2 . Q^{\prime}}^{\prime} f_{3 . Q^{\prime}}^{\prime} f_{4 . Q^{\prime}}^{\prime} f_{5 . Q^{\prime}}^{\prime} f_{6 . Q^{\prime}}^{\prime} f_{7 . Q^{\prime}}^{\prime}$ and $f_{8 . Q}^{\prime} \cdot$ 
Table 9: Optimal results for the same set of values as in Example 4.2 for different constant demand rates.

\begin{tabular}{|c|c|c|c|c|c|c|c|c|c|c|c|c|}
\hline$\alpha$ & $Q^{*}$ & $q_{1}^{*}$ & $q_{2}^{*}$ & $t_{1}^{*}$ & $t_{2}^{*}$ & $t_{3}^{*}$ & $t_{4}^{*}$ & $t_{5}^{*}$ & $t_{6}^{*}$ & $t_{7}^{*}$ & $t_{8}^{*}$ & $Z\left(Q^{*}, q_{1}^{*}, q_{2}^{*}\right)$ \\
\hline 640 & 1645 & 871 & 53 & 0.1544 & 0.9070 & 2.1625 & 2.1845 & 2.2030 & 2.2654 & 2.33903 & 2.5856 & 5949.82 \\
\hline 720 & 1683 & 829 & 129 & 0.1582 & 0.9278 & 2.0026 & 2.0517 & 2.1022 & 2.2700 & 2.43081 & 2.6421 & 6774.6 \\
\hline 800 & 1712 & 781 & 191 & 0.1605 & 0.9436 & 1.8634 & 1.9292 & 2.0117 & 2.2888 & 2.5049 & 2.6851 & 7616.1 \\
\hline 880 & 1735 & 729 & 236 & 0.1614 & 0.9562 & 1.7424 & 1.8180 & 1.9347 & 2.3220 & 2.56647 & 2.7191 & 8467.36 \\
\hline 960 & 1756 & 674 & 265 & 0.1626 & 0.9677 & 1.638 & 1.7164 & 1.8670 & 2.3675 & 2.62061 & 2.7501 & 9323.28 \\
\hline
\end{tabular}

Table 10: Optimal results for the same set of values as in Example 4.2 for different variable demand rates.

\begin{tabular}{|c|c|c|c|c|c|c|c|c|c|c|c|}
\hline $\begin{array}{ll}\beta & Q^{*} \\
\end{array}$ & $q_{1}^{*}$ & $q_{2}^{*}$ & $t_{1}^{*}$ & $t_{2}^{*}$ & $t_{3}^{*}$ & $t_{4}^{*}$ & $t_{5}^{*}$ & $t_{6}^{*}$ & $t_{7}^{*}$ & $t_{8}^{*}$ & $Z\left(Q^{*}, q_{1}^{*}, q_{2}^{*}\right)$ \\
\hline 331732 & 792 & 192 & 0.1613 & 0.954628 & 1.88977 & 1.95572 & 2.03776 & 2.31463 & 2.53282 & 2.71471 & 7586.86 \\
\hline 341722 & 787 & 191 & 0.160409 & 0.949159 & 1.87717 & 1.94361 & 2.02664 & 2.30292 & 2.51948 & 2.69991 & 7601.52 \\
\hline 351712 & 781 & 191 & 0.160528 & 0.94369 & 1.86346 & 1.92922 & 2.01177 & 2.28889 & 2.50498 & 2.6851 & 7616.1 \\
\hline 361702 & 776 & 190 & 0.159656 & 0.93822 & 1.85094 & 1.91713 & 2.00059 & 2.27709 & 2.49157 & 2.67029 & 7630.6 \\
\hline 371692 & 772 & 190 & 0.157792 & 0.93275 & 1.83961 & 1.90504 & 1.98791 & 2.26524 & 2.47926 & 2.65547 & 7645.01 \\
\hline
\end{tabular}

From (4.29)-(4.33), and (4.25) we have

$$
\begin{aligned}
w_{Q Q}^{\prime}=\left(c_{m}+s_{m}\right)\left\{f_{6 . Q}^{\prime} P_{m}\left(f_{6}\right)-f_{4 . Q}^{\prime} P_{m}\left(f_{4}\right)\right\}+c_{R} f_{8 . Q}^{\prime} R\left(f_{8}\right)+s_{r} f_{2 . Q}^{\prime} P_{r}\left(f_{2}\right) \\
+h_{r}\left\{f_{1 . Q}^{\prime}\left(f_{1}-f_{2}\right)\left(P_{r}\left(f_{1}\right)-D\left(f_{1}\right)\right)+f_{3 . Q}^{\prime}\left(f_{3}-f_{2}\right) D\left(f_{3}\right)\right\} \\
+h_{m}\left\{f_{5 . Q}^{\prime}\left(f_{5}-f_{6}\right)\left(P_{m}\left(f_{5}\right)-D\left(f_{5}\right)\right)-f_{7 . Q}^{\prime}\left(f_{7}-f_{6}\right) D\left(f_{7}\right)\right\} \\
+h_{R}\left\{f_{8 . Q}^{\prime} f_{2} R\left(f_{8}\right)-f_{2 . Q}^{\prime} f_{8} R\left(f_{2}\right)\right\} \\
+c_{s}\left\{f_{3 . Q}^{\prime}\left(f_{3}-f_{4}\right) D\left(f_{3}\right)+f_{5 . Q}^{\prime}\left(f_{5}-f_{4}\right)\left(P_{m}\left(f_{5}\right)-D\left(f_{5}\right)\right)\right. \\
\left.\quad+f_{8 . Q}^{\prime} f_{1} D\left(f_{8}\right)+f_{7 . Q}^{\prime}\left(f_{7}-f_{8}-f_{1}\right) D\left(f_{7}\right)\right\} .
\end{aligned}
$$

From which and (4.28) we obtain

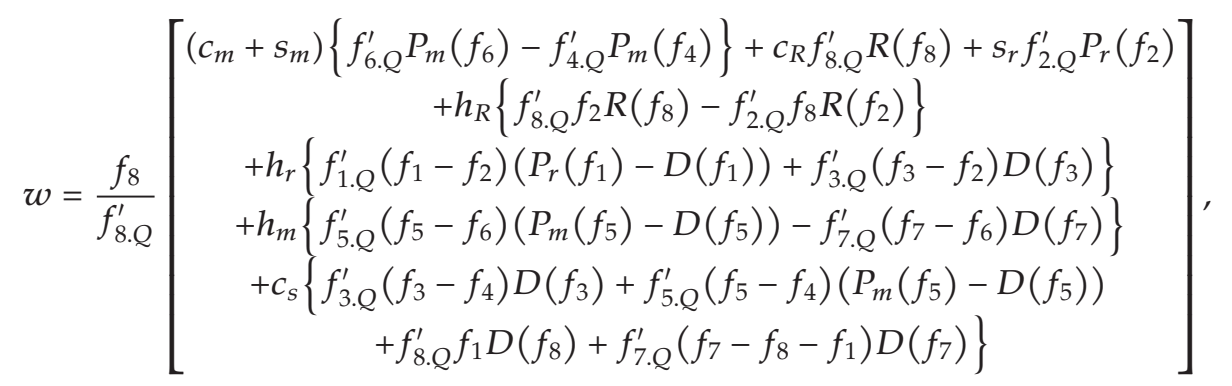

where $W$ is given by (4.25) and $w_{Q}^{\prime}$ is given by (4.34).

Equation (4.35) can now, be used to determine the optimal value of $Q$. If we get more than one solution we choose the one for which the condition $d^{2} W / d Q^{2}>0$ is satisfied. 
Table 11: The optimal results for the inventory model under the parametric values given in Example 4.2.

\begin{tabular}{lccccccccc}
\hline$Q^{*}$ & $t_{1}^{*}$ & $t_{2}^{*}$ & $t_{3}^{*}$ & $t_{4}^{*}$ & $t_{5}^{*}$ & $t_{6}^{*}$ & $t_{7}^{*}$ & $t_{8}^{*}$ & $Z\left(Q^{*}, q_{1}^{*}, q_{2}^{*}\right)$ \\
\hline 1737 & 0.155131 & 0.957362 & 1.89856 & 1.95774 & 2.03215 & 2.32237 & 2.5483 & 2.7221 & 7616.6 \\
units & Month & month & month & Month & Month & Month & Month & month & $\$$ \\
\hline
\end{tabular}

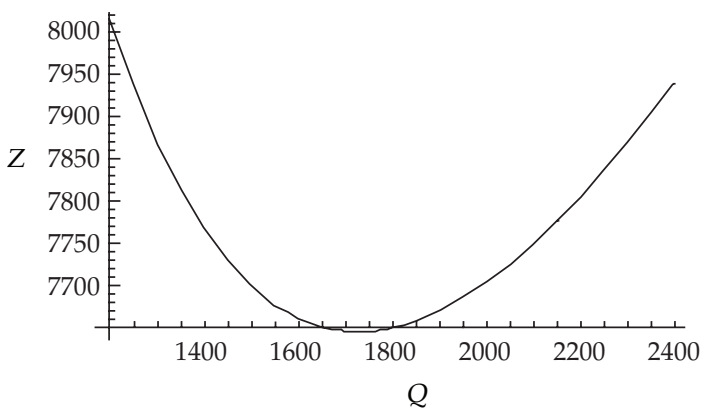

Figure 4: Behavior of the inventory cost function, when the values of $q_{1}$ and $q_{2}$ are taken to be constant.

Then the optimal values of $t_{1}, t_{2}, t_{3}, t_{4}, t_{5}, t_{6}, t_{7}$, and $t_{8}$ can be determined by using (4.9)-(4.23). From the above-mentioned results we can determine the value of $w_{Q}^{\prime}$ and $w$. Hence from (4.25) we can get the minimum total average cost.

Example 4.3. The same set of input data are considered as in the Example 4.2 except that the constant values of $q_{1}$ and $q_{2}$ are as follows: $q_{1}=800$ units, $q_{2}=200$ units.

Applying the solution procedure given in last section we find that the optimal value of the acceptable returned quantity $Q$ is 1737 and hence the corresponding optimal results are presented in Table 11 .

The convexity of the total cost function has been established graphically in Figure 4 it has also been verified numerically that the cost function is convex.

\section{Conclusion}

In this paper designed model for a supply chain network with reverse flows is proposed. This paper generalises a reverse logistics inventory model for integrated production of new items and remanufacturing of returned items with shortages. In many practical situations, stock out is unavoidable due to various uncertainties. Therefore, the occurrence of shortages in inventory is a natural phenomenon. The developed model is solved by using the Hessian matrix. Results presented herein provide a valuable reference for decision makers in production, storage remanufacturing, and returning planning. A numerical example demonstrates that applying the proposed model can minimize the total average cost. In addition, sensitivity analysis is performed to examine the effect of parameters. According to those results, the presented model is least sensitive with respect to the production and remanufacturing rates while enough sensitive with respect to the returned and demand rates. It can be concluded from the obtained results that the higher returned rate can provide more profit. A future study should incorporate more realistic assumptions into the proposed model, for example, stochastic nature of demand, production, and remanufacturing rates follow learning and forgetting curves, and consider multiple production and remanufacturing batches per interval. 


\section{Acknowledgments}

N. Saxena would like to express her thanks to University Grants Commission India for providing financial help in the form of junior research fellowship. The authors also thank the anonymous referees for their positive reviews.

\section{References}

[1] D. A. Schrady, "A deterministic Inventory model for repairable items," Naval Research Logistics Quarterly, vol. 14, no. 3, pp. 391-398, 1967.

[2] S. Nahmias and H. Rivera, "A deterministic model for a repairable item inventory system with a finite repair rate," International Journal of Production Research, vol. 17, no. 3, pp. 215-221, 1979.

[3] M. Fleischmann, J. M. Bloemhof-Ruwaard, R. Dekker, E. Van Der Laan, J. A. E. E. Van Nunen, and L. N. Van Wassenhove, "Quantitative models for reverse logistics: a review," European Journal of Operational Research, vol. 103, no. 1, pp. 1-17, 1997.

[4] M. C. Mabini, L. M. Pintelon, and L. F. Gelders, "EOQ type formulations for controlling repairable inventories," International Journal of Production Economics, vol. 28, no. 1, pp. 21-33, 1992.

[5] K. Richter, "The EOQ repair and waste disposal model with variable setup numbers," European Journal of Operational Research, vol. 95, no. 2, pp. 313-324, 1996.

[6] K. Richter, "The extended EOQ repair and waste disposal model," International Journal of Production Economics, vol. 45, no. 1-3, pp. 443-447, 1996.

[7] K. Richter, "Pure and mixed strategies for the EOQ repair and waste disposal problem," OR Spektrum, vol. 19, no. 2, pp. 123-129, 1997.

[8] R. H. Teunter, "Economic ordering quantities for recoverable item inventory systems," Naval Research Logistics, vol. 48, no. 6, pp. 484-495, 2001.

[9] S. G. Koh, H. Hwang, K. I. Sohn, and C. S. Ko, “An optimal ordering and recovery policy for reusable items," Computers and Industrial Engineering, vol. 43, no. 1-2, pp. 59-73, 2002.

[10] R. Teunter, "Lot-sizing for inventory systems with product recovery," Computers and Industrial Engineering, vol. 46, no. 3, pp. 431-441, 2004.

[11] K. Inderfurth, G. Lindner, and N. P. Rachaniotis, "Lot sizing in a production system with rework and product deterioration," International Journal of Production Research, vol. 43, no. 7, pp. 1355-1374, 2005.

[12] I. Dobos and K. Richter, "A production/recycling model with stationary demand and return rates," Central European Journal of Operations Research (CEJOR), vol. 11, no. 1, pp. 35-46, 2003.

[13] I. Dobos and K. Richter, "An extended production/recycling model with stationary demand and return rates," International Journal of Production Economics, vol. 90, no. 3, pp. 311-323, 2004.

[14] I. Dobos and K. Richter, "A production/recycling model with quality consideration," International Journal of Production Economics, vol. 104, no. 2, pp. 571-579, 2006.

[15] I. Konstantaras and S. Papachristos, "Optimal policy and holding cost stability regions in a periodic review inventory system with manufacturing and remanufacturing options," European Journal of Operational Research, vol. 178, no. 2, pp. 433-448, 2007.

[16] I. Konstantaras and S. Papachristos, "A note on: developing an exact solution for an inventory system with product recovery," International Journal of Production Economics, vol. 111, no. 2, pp. 707-712, 2008

[17] I. Konstantaras and S. Papachristos, "Note on: an optimal ordering and recovery policy for reusable items," Computers and Industrial Engineering, vol. 55, no. 3, pp. 729-734, 2008.

[18] M. Y. Jaber and A. M. A. El Saadany, "The production, remanufacture and waste disposal model with lost sales," International Journal of Production Economics, vol. 120, no. 1, pp. 115-124, 2009.

[19] M. Omar and I. Yeo, "A model for a production-repair system under a time-varying demand process," International Journal of Production Economics, vol. 119, no. 1, pp. 17-23, 2009.

[20] A. M. A. El Saadany and M. Y. Jaber, "A production/remanufacturing inventory model with price and quality dependant return rate," Computers and Industrial Engineering, vol. 58, no. 3, pp. 352-362, 2010.

[21] A. A. Alamri, "Theory and methodology on the global optimal solution to a General Reverse Logistics Inventory Model for deteriorating items and time-varying rates," Computers and Industrial Engineering, vol. 60, no. 2, pp. 236-247, 2011. 
[22] I. Konstantaras, K. Skouri, and M. Y. Jaber, "Lot sizing for a recoverable product with inspection and sorting," Computers and Industrial Engineering, vol. 58, no. 3, pp. 452-462, 2010.

[23] P. Hasanov, M. Y. Jaber, and S. Zolfaghari, "Production remanufacturing and waste disposal model for a case of the cases of pure and partial backordering," Applied Mathematical Modelling, vol. 36, no. 11, pp. 5249-5261, 2012.

[24] P. C. Yang, S. L. Chung, H. M. Wee, E. Zahara, and C. Y. Peng, "Collaboration for a closed-loop deteriorating inventory supply chain with multi-retailer and price-sensitive demand," International Journal of Production Economics. In press, http:/ / dx.doi.org/10.1016/j.ijpe.2012.07.020 .

[25] I. Konstantaras and K. Skouri, "Lot sizing for a single product recovery system with variable setup numbers," European Journal of Operational Research, vol. 203, no. 2, pp. 326-335, 2010.

[26] M. Y. Jaber and A. M. A. El Saadany, "An economic production and remanufacturing model with learning effects," International Journal of Production Economics, vol. 131, no. 1, pp. 115-127, 2011. 


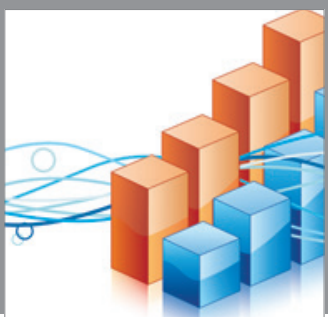

Advances in

Operations Research

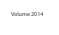

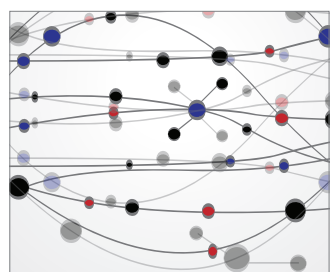

\section{The Scientific} World Journal
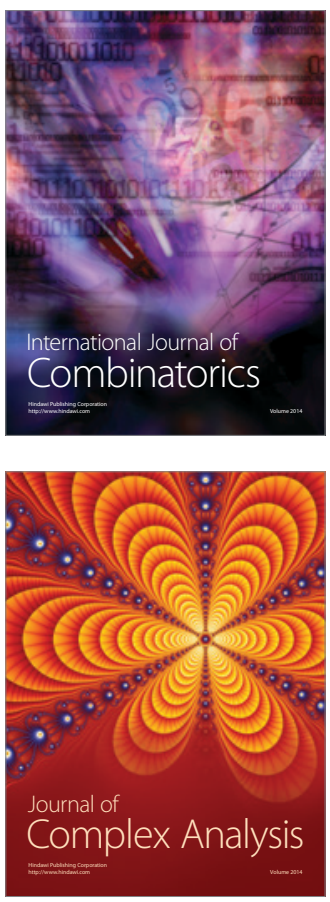

International Journal of

Mathematics and

Mathematical

Sciences
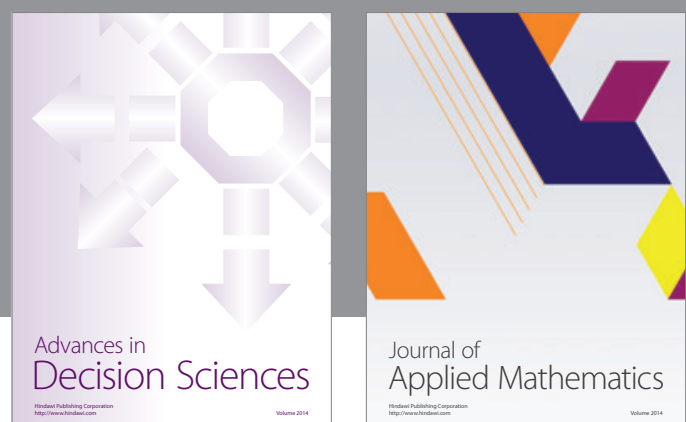

Journal of

Applied Mathematics
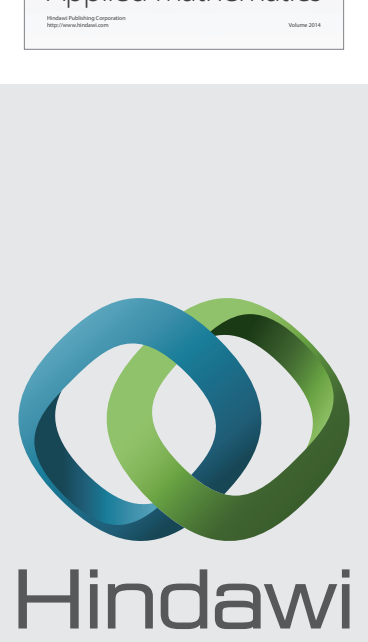

Submit your manuscripts at http://www.hindawi.com
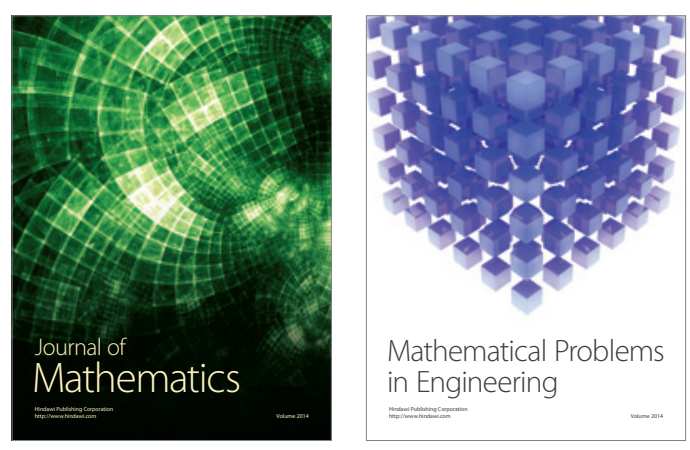

Mathematical Problems in Engineering
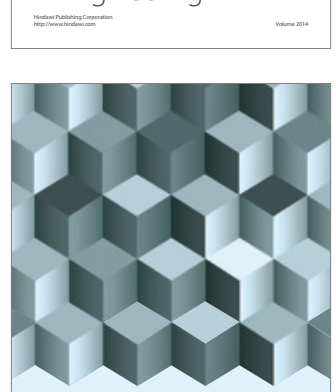

Journal of

Function Spaces
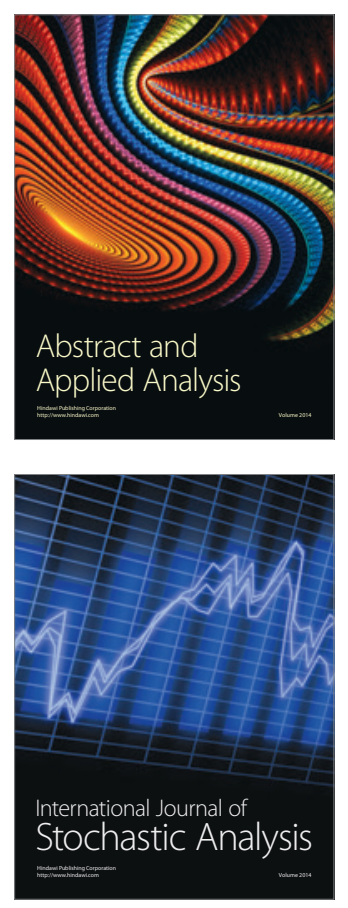

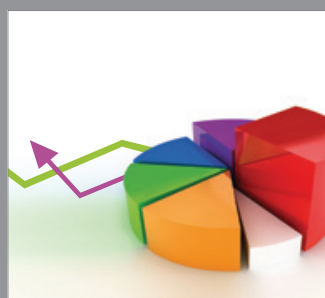

ournal of

Probability and Statistics

Promensencen
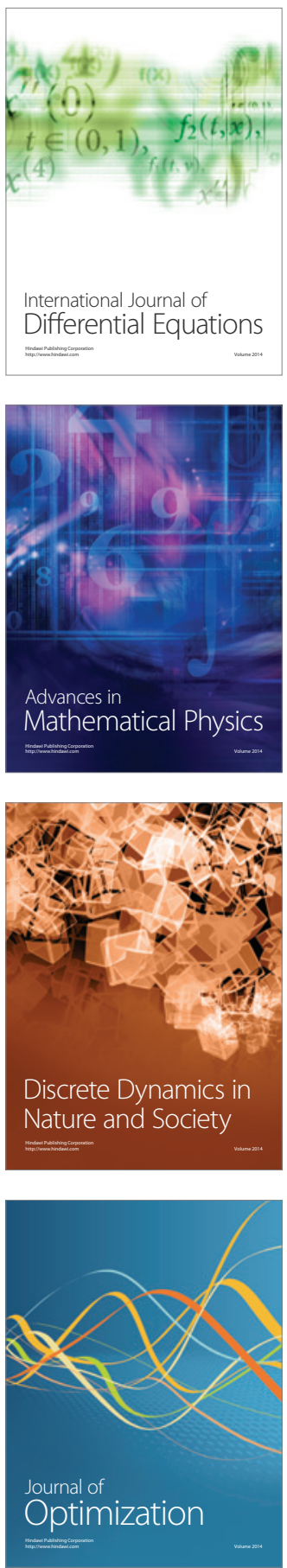